\title{
The legacy of Sir Reginald Stephen Garfield Todd in Zimbabwean public life history
}

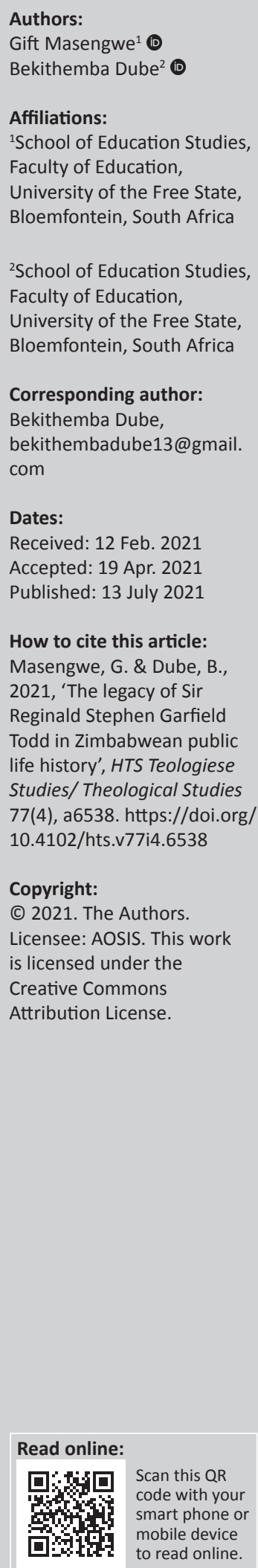

This article investigates the contribution of white liberal politics of an ex-missionary New Zealander, Sir Reginald Stephen Garfield Todd (from 1953 to 1958), on the development of Southern Rhodesia towards becoming an independent state. It outlines the contribution he made towards the progress of black Zimbabweans in a number of spheres. It arouses interest in contemporary Zimbabwean religious and political discourses. Todd held a hybridity of roles in transitional politics from the blunting settler racism to the sharpening of African capability on multi-racial democracy important for our debate on the decolonisation of southern Africa. He was a rhetorically gifted radical paternalist who adopted reformist policies to advance both the African cause and his prophetic vocation. He suggested technocratic solutions that could reorganise and diversify political and economic options.

Contribution: This study uses critical discourse analysis (CDA) on the wider literature on Todd's biography and African policies in view of his Christian vocation towards changing conditions of socio-economic, political-religious and technological-technocratic solutions to contemporary African independence. He was a man of his times living and working in an increasingly problematic context guided by the Christian principles in which he was reared. He is the 'father of faith' in the Church of Christ in Zimbabwe (COCZ), and leaves us pedagogical lessons on human security, gender equality, church governance and human well-being that require review within the contemporary Christian fraternity.

Keywords: Sir Reginald Stephen Garfield Todd; Church of Christ in Zimbabwe (COCZ); decolonisation; Dadaya Mission; Zimbabwean history; the Black Moses.

\section{Introduction}

Sir Reginald Stephen Garfield Todd (1908-2002) was an ex-missionary New Zealander of the Disciples of Christ who came to Zimbabwe and later on acquired both permanent residence and citizenship. He is captured as a radical paternalist and white liberal who condemned a suburban white regime representing the minority at the expense of an increasingly conscious African nation that, like other Central African Federation (1953-1963) counterparts, Malawi and Zambia, who earlier on embraced winds of change (Welensky 1964) was on the same path (White 2015:29). Todd's policy scale and impact on African education, health justice, single Industrial Conciliation labour policy, gender equality, voting enfranchise, urbanisation and agrarian justice propelled Africans to take up national and religious leadership (Wilson 2020:1).

This article proposes that Todd's reformist policies and rhetorics could reconcile racial politics and nationalist liberalism useful for multi-racial democracy in a decolonised Zimbabwe (King 2001:12). The politically untutored Todd's Christianity and New Zealand forms of democratic equality were the only orientation he used in his leadership of the nation and the Church because no earlier missionary assisted him on how to racially discriminate Africans (Paul \& Grundy 2011:629). With no 'prohibitions' and 'inhibitions', he created opportunities for future Zimbabwean leadership through the education of young Africans, and later when he became a constituency representative created policies to support his earlier ideas. Missing Garfield Todd in the annals of Zimbabwe renders its colonial and independent history inadequate and incomplete. He earned a nickname, 'Shumba Chena' (Vundla 2015), meaning White Lion because of the sacrifices he made for enfranchising Africans into the white political and economic power (Todd 1985:2). Shumba (Lion) is a totemic emblem for the people of Lundi Native Reserve (LNR) shown by exhibiting bravery and resilience against enemies and prey. He endured untold suffering during and after the colonial era. 


\section{The early life of Todd and his family life}

Todd was a native of New Zealand, born at Invercargill in 1908 and was named after the United States President James A. Garfield. He was educated at Otago University, and then in 1931, took holy orders at Glen Leith Theological College there. There, he worked at his father's brick-making business, which gave him experience to build Dadaya Mission into a renowned educational centre easily. He was married to Jean Grace Wilson and had three daughters and the first was an adopted child. He came to the University of the Witwatersrand in South Africa in 1932 disrupting his posting to South Africa, and in 1934, he was posted to Dadaya, as a Protestant missionary 'in the Associated Churches of Christ in New Zealand, a non-denominational Christian body' (West 1992:301), 40 years after the establishment of colonialism. This means Garfield Todd was preceded by several New Zealand COCZ missionaries (Masengwe 2020:35). Missionaries included the self-supporting mason, John Sherriff (1864-1935) in 1896 (Lusby 1990:7; Zvobgo 1996:79), trained missionaries, Mr and Mrs F.L. Hadfield in 1906 (Bhebhe 2013:138), Scottish watchmaker Thomas Anderson in 1907 (Lusby 1990) and Mr and Mrs A. Bowen in 1931 (Lusby 1990:2) and then Mr and Mrs Garfield Todd in 1934 (Lusby 1990:10). He was the most significant missionary of the COCZ despite the 1929-1930 Great Depression and the 1939-1945 Second World War by inviting former American military man, Mr. John C. Pemberton and his wife in 1956 to take over Mashoko whilst he kept Dadaya (Bhebhe 2013:140; Lusby 1990:10).

Todd's childhood is not clearly elaborated in Zimbabwean history. He came to Zimbabwe as a missionary of the Restoration faith in 1934 at the age of 26 years (Paul \& Grundy 2011:629). These Christian churches 'strike some as a strange quest: to restore the primitive church found in the pages of the New Testament' (Casey 2007:489). This is a common tradition across all of the Commonwealth British countries. It remained distinguished because of its 'rational cast' across all three main traditions of the Churches of Christ: conservative (noninstrumentals), liberal (Disciples of Christ) and independent (Christian Churches) (Casey 2004:491; Casey \& Foster 2002; Harrell 1966; Hughes 1996; Tucker \& McAllister 1975; Webb 2003). Todd inherited an ideal passed on from Alexander Campbell in terms of hermeneutics and preaching: 'rational calculi' or 'common sense realism', also called 'Baconian Method of inductive reasoning in all areas of knowledge, including scriptural interpretation and authorisation of church practices' (Casey 2004:490). The theology and practices of churches that used the restoration ideal were incomparable in energy and direction that they produced the most Bible linguists, commentators, debaters, translators, polemicists, historians and the most able Bible students in the United States of America (Berryhill 1988; Casey 2001).

Todd acquired unique and robust Campbellian religious heritage at Glen Leith College of the Churches of Christ in New Zealand, where he took homiletics, elocution and logic in preparation for the broader frontier Christianity of the
Stone-Campbell Movement (Casey 2004:492; eds. Williams, Allen \& Blowers 2013). At Dadaya, he displayed the skill and acumen of a Campbellite in organisational leadership, entrepreneurial distinction and ecumenical values. He built, under severe budgetary constraints, a renowned educational institution. He gained a parliamentary seat 12 years after his arrival into the country (1946), premiership 7 years later (1953) and was ousted 5 years later (1958) because of his liberal policies. This background formed his conception of colonialism.

\section{Todd's conception of colonialism}

Todd saw in colonialism a means to transform African communities into modern societies. In the following, Garfield Todd's attitude towards colonialism is clearly displayed. Under Garfield Todd, the Zimbabwean economy was leveraged and diversified because of the Federation; however, his acceleration of African education, and hence his final ousting from power, shaped the African nationals' confrontation of the regime (Pritchard 2018:95). His commitment to advance Africans led to his removal from leading the United Federal Party (UFP), marking the decline in limited reforms (Raftopolous 1995:90), which possibly intensified African resistance to colonial rule. On African hopes pinned on his liberal policies, Woodhouse recorded Todd in an audiotape saying, '[t]he noise of my falling, as I was thrown out, awakened the [African] nationalist cause' (Woodhouse 2018:257). Possibly Todd's efforts could have led the country to decolonise itself and liberalise the economy, a process that was halted by a cabinet revolt against Todd's 'pro-African policies' (Mlambo 2009:106). It was then that they turned their backs on white liberals and joined hands with the masses that they had spurned in the past to build a militant African nationalist movement that was now demanding 'one man, one vote' (Mlambo 2009:95). African intellectuals who realised that Rhodesia had departed from the route of decolonising itself by partnering with African middle-classes like ‘Bernard Chidzero, Enoch Dumbutshena, Herbert Chitepo, Reverend Ndabaningi Sithole, Robert Mugabe and others' (Raftopolous 1995:90) joined national politics in 1960 by forming the National Democratic Party (NDP) after the African National Congress (ANC) was banned (King 2001:12). They decided to confront 'the rightward drift in white politics ... [that decreased] ... space for the black elite to develop in the colony' (Raftopolous 1995:90). Todd, distinguished because of his faith, education and oral skills - 'could speak 200 words a minute to the applause of delegates and to the dismay of opponents', which gave him ability to speak forcefully for the African cause. His conception of colonialism because of his faith led him to serve the maltreated, poor and oppressed Africans who lost land and animals to colonialists during the Land Apportionment Act of 1930. He invested every resource he got his hands on in order to empower Africans. He actually used his own income from the government to buy land for Dadaya Mission which previously had a small space. He bought Hokonoui Farm near the perennial flow of water from the Ngezi River and the railway line to relocate the mission (Paul \& Grundy 
2011:635). The farm was substantially huge that he also accommodated African farmers from overcrowded communal areas. There, he built one of the top notch schools in the country for Africans, which became his home: to live, to die and to be buried.

His commitment to African transformation, as Kapungu alluded, can be highlighted in what he said more than what he did about African education, fair and decent wage labour, African voting enfranchise, gender equality for education and jobs and right to land for animal and crop husbandry (Kapungu 1974:31). His speeches went before international platforms to isolate and to polarise the racism of the colonialist regime, to liberalise the economy and to legitimise the liberation struggle (Leaver 2006:175). He earned not only knighthood but also a national hero status (Mungazi 1999:130; Pritchard 2018:95). We are reflecting on him because his character is unparalleled in religion and in politics, he polarised racism, liberalised the economy and made the church ecumenical. This personality is probably a product of the type of faith he had received, the Restoration Theology (Casey 2007; Lowry 2007a, 2007b). That's why A.S. Chigwedere, a prominent ZANU-PF leader, a public servant and a prolific writer on cultural nationalism; the former Minister of Education (2001-2009) and the Provincial Governor (2008-2013) says in his book, The White Heroes, 'He [Garfield Todd] was simply the white African Moses who delivered the black Zimbabweans out of bondage' (2017:231; Casey 2007:6465). Some COCZ members, however, regard Todd as a white Joseph turned into a Moses for the colonised indigenes as he holds multiple faces of an able administrator and a liberator for the Africans. His educational policies resourced Africans to demand and fight for their political rights.

\section{Tenure in office as prime minister of Rhodesia}

Todd's tenure in office as a legislator and later prime minister focused on increasing or improving African education, fair and decent wage labour, African voting enfranchise, gender equality for education and jobs and right to land for animal and crop husbandry. He used every opportunity to carve his name on human hearts rather than on tombstones (Shannon L. Adler), becoming a human letter written on human hearts (2 Cor 3:1-3). He took responsibility to create a lasting legacy for the next generation he did not imagine (Jim Rohn). Todd achieved most of his goals even though he did not last long in power as the prime minister, and they actually became the source of his major contestations.

\section{The five-year plan (1953-1958) and the expansion of African education}

Mission schools were run according to the 1959 African Education Act, and were responsible for providing education to Africans, but the outbreak of the Second World War between 1939 and 1948 led to inflation, undermining the ability of mission centres to feed the doubling numbers of student enrolments, which rose from 95000 to 210000 , during the time of John Huggins (Mlambo 2009:85-87). Mission schools became heavily dependent on government funding to offset their diminishing foreign churches' support/sponsorship. Todd used his experience at Dadaya 'to interpret the wishes of Africans to Europeans and make the latter aware of the worth and abilities of blacks' (Paul \& Grundy 2011:634). He introduced modest 5-year free black educational reforms at most pioneering Mission schools like Dadaya, Kutama, Goromonzi, Gokomere, and St. Augustine's that taxed British authorities and property owners (Mason 1960:187). Todd's move was still 'not sufficient to stay abreast of rising prices and an expanding student body' (West 1992:300). In his intellectual framing, Todd wrestled away African Education from Native Affairs for purposes of logistical support to African professionals who formed the rural intelligentsia and for training of school leavers in rural, urban, farming and mining areas (Chigwedere 2017). This made his conservative opposition unhappy because the products of this 5-year plan became skilled labourers that formed a new generation of African middle-classes that qualified for university education and ammunition for the liberation struggle (Paul \& Grundy 2011:636). The plan, which was only for 5 years, achieved more because he institutionalised it by having partnerships that used diverse routes of financial sustainability for African education such as increased African taxation for African education (Richards \& Govere 2003:137-151).

Todd became concerned about the educational prospects of young Africans who became caught up in the struggle for independence (Woodhouse 2018:59). Todd, who inherited Scottish Baconian philosophy, felt distantly connected to Britain as he realised that the war of liberation was going to exert irresistible pressure on African countries, which is why he wrote (Woodhouse 2018):

$[A]$ frica is just as great a question mark as ever, though, and I do not think we will extricate ourselves from the tragedy of the colour-bar unless America and the Dominions take an interest in us and lend us their strength. (p. 62)

Africans had been inspired by the WWII and Todd knew the aspirations of African intellectuals, hence he prioritised African education because he believed his African students could lead the nation and church (Todd 1972). Every resource that came Todd's way went to equip African nurses, teachers and agricultural demonstrators to the extent of using his family inheritance. For Dadaya to be specific, he testified that: 'Africans are beginning to see visions and dream dreams and at Dadaya we have some who may become leaders of their people' (Woodhouse 2018:59). This saw good civil servants, politicians and professionals such as Mr. Manikidza M. Nyoni, the first black principal of Dadaya and mayor of Gweru, Rev. Ndabaningi Sithole, Grace Todd's brightest student who became ZANU Party's president in 1963 and Mr. Kingsley Dinga Dube who became the United Nations civil servant and Mr. Tembo Ncube, the 1980s and 1990s Bulawayo renowned orthopaedic surgeon (Paul \& Grundy 
2011:633-634). 'Todd's products were corrupt-free civil servants who were committed to national development and the work of God' (Nyoni 2018). The 'Todd Factory' (Chigwedere 2017) was never thought to produce prominent national leaders who later influenced the liberated country to introduce free primary and secondary education to all those who could attend school at that time. The actions and attitudes of Todd towards African education are a legacy and challenge for the COCZ history on African advancement. Contemporary church and state players need to seriously plan how education can be diversified and intensified for national development.

\section{The transformation of African intellectuals, professionals and middle-classes}

Todd's advocacy for a single Industrial Conciliation Act to bring income security to African labourers was part of his 5-year training programme that transformed African workers into a stable middle-class generation of industrial labourers and professional workers (Wilson 2020). Africans could no longer be regarded as mere labourers in undignified and unattractive forced cheap labour on white-owned mines, farms and factories to raise taxes for all men of 16 years and above. Discontented Africans did not want to pay taxes whose use they did not understand and were angry of government confiscation of their property, like cattle, to pay taxes during drought years at dishearteningly cheap prices to pay taxes in order to force men to work for white entrepreneurs. '[M]ost natives preferred to pursue their [own] traditional life of agriculture and herding than work for the white-men (sic)' (Makwasha 2011:237). Todd advanced working conditions and remuneration for African labourers including decent accommodation, and sanitary and medical supplies by a single Industrial Conciliation Act he advocated in favour of equal treatment between black people and white people doing the same jobs. This was supported by policy changes in the training of Africans to take opportunity in the increasing labour demand in the growing industry. He stated in the 1957 parliament (Chigwedere 2017):

$[W]$ e must get away on the one hand from the feeling that if the African advances and becomes educated, the European is going to suffer, and on the other hand, we must come to a fuller realisation that unless we are able to provide the type of African labour industry wants, industry is not going to be set up here extensively as we would like to see. (p. 278)

Africans who did not understand the implications of the Todd policies had begun to strike in factories and schools. Todd's liberal policies, however, could have prevented a fullfledged war of liberation, for he promoted gainful employment. This is a hard lesson for churches that, like secular institutions, owe workers large sums of unpaid wages and allowances and do not pay minimum wages and engage in underhand deals. Todd humanised the public labour system that did not discriminate against child labour, and when husbands went missing, wives were taken hostage until husbands returned to rescue them. The towering example of Todd on human dignity at work speaks volumes to the contemporary church and the state where informality seems to be highly emulated compared to professionalism.

\section{The modernisation of African healthcare services}

Todd became committed to maternal health and education to prevent infant and child mortality. Various women who came for maternal delivery at his de facto maternity home shared the little space in his own home (Paul \& Grundy 2011:632):

Though he had no formal medical training, Todd and his wife, Grace, set up a clinic where he delivered hundreds of babies (some who were named after him) and treated minor injuries. (Vundla 2015:11)

He also delivered his own two daughters. According to modern standards, Garfield's clinic gave deliveries to all maternity cases he encountered expertly, except the one case that haunted him, of a tiny baby who for $2 \mathrm{~h}$, he tried to resuscitate by breathing vital air into her lungs, and as soon as he stopped, she also stopped. Apart from this, he also successfully treated child burns for more than 12000 inhabitants of LNR using motor oil. With rudimentary medical knowledge, he gained knowledge to successfully help people with a variety of health challenges there. In 1941, Todd is recorded saying:

[W] e must carry on the work of healing. Through this service, we have come very near to the life of the people and have grown to know and understand them more fully than we might otherwise have done. (p. 1)

This testifies to Stella Todd, a nurse and sister to Garfield, who came in 1936 to Dadaya, who said they 'extracted teeth from their veranda, treated burns in the eating room and delivered babies in the bathroom'. Their house was turned into a de facto clinic, except for referral cases. This gave him enough experience to advocate the training of African nurses as state certified and state registered nurses when he became the premier. Earlier on, he had trained African first-aiders from his brightest senior students like the late Rev. Ndabaningi Sithole to relieve the overworked 'doctor' (Casey 2007). Girls were taught on home care nursing and paediatric care to babies born in Todd's house. African healthcare services were the responsibility of the Federal government; hence, in 1958, he launched the training of African State Registered Nurses at Mpilo and Harare hospitals to serve the nation's changing demands for western medicine from African traditional medicine. Investments for this took place in rural district hospitals and mission hospitals, with a remarkable population increase between the 1950s and the 1980s, the weight of numbers that led to the success of the liberation struggle (Chigwedere 2017:247). With a significant drop in infant and child mortality during this period, the population demographic revolution went up fourfold because of maternal education and access to healthcare, the Rhodesia Front rule tried to reverse with little success (Wilson 1990). The contemporary collapse of the national healthcare system with adequate financial and logistical support in the 
nation becomes a cause for concern for everyone when one person was committed to serve people of a different race to him. This gives us a huge lesson for the transformation of Zimbabwe's healthcare services.

\section{The expansion of the African voting enfranchise}

Paul and Grundy (2011:633) state that 'Garfield's unique formative years meant he always stood at a slight angle to the rest of white society'. Firstly, Garfield Todd came to LNR at Dadaya Mission and lived amongst Africans for many years before he engaged in national politics. In his $1970 \mathrm{draft}$ autobiography, Todd stated:

$[W]$ e were fortunate to recognise so early in our time in Africa, not only that the future lay with the African people in themselves but that in the sleepy villages, basking in the sun, were the people who could and would take the future into their own hands. (p. 1)

Todd's advocacy for black voting rights was meant to humanise Africans as equals to whites in terms of selfdetermination. He argued for blacks eligible to vote to increase from $2 \%$ to $16 \%$, which lowered voting requirements on education and property values owned by blacks. Even on leaving office, his farewell statement (Todd 1958) was:

[W]e must make it possible for every individual to lead the good life, to win a place in the sun. We are in danger of becoming a race of fear-ridden neurotics - we who live in the finest country on earth. (p. 2)

This would increase the number of Africans on the voter's roll to between 6000 and 10000 people. This led to Todd being labelled as a tactless ultra-liberal (Leys 1959:142). The voter's roll spelt out the fears of whites who were concerned about losing their privilege and supremacy (Hintz 1972:173-183; Kealy 1963:249-250, 436-437; Mason 1960:193; Zvobgo 2009:102-104); hence, success with Africans (Mlambo 2009:116) became 'Todd's graveyard' (Chigwedere 2017:288) or 'Todd Grave Diggers' (Todd 1982:54). The issue of ethno-centricism has been on resurgence in post-independent Zimbabwe (De Gruchy 1995:124). This has implications for the quality of Christian ministers who can no longer sustain their work on basic training like evangelist Rev. J.N. Hlambelo, an itinerant preacher from Dadaya to Dorset in lower Gweru, for they could be designated as preaching a weak or wrong gospel like Anglican preachers who were once labelled like that (Makwasha 2011:243). Using the Campbellian religious values, Todd advocated political liberty in voting which began in 1920 for white people only until independence in 1980 (Banana 1989:199). Voting is a contentious issue that requires proper approaches and procedures to attain democracy in Zimbabwe. Todd advocated for African leadership, an issue that must poke African leaders to advance democratic elections rather than suppress justice through vote buying and rigging.

\section{Towards gender and sexual equality in education, work and society}

Todd came from a tradition where women were treated with respect and were allowed to vote in 1893. In the LNR, very few girls attended the village school which had only up to standard 3. 'The Todds were shocked to find that most African parents [including some teachers] regarded education as something for boys only' (Paul \& Grundy 2011:631). Todd admitted girls to the central boarding school, and by 1935 started the ambitious project of constructing girls' clay and dagga dormitories. Proudly, 'The girls quickly proved themselves, and for several years two exceptionally bright ones topped their year, much to the chagrin of boys' (Paul \& Grundy 2011:631). Grace Todd, the designer of the Zimbabwean Primary School Education System in Zimbabwe, who initially meant to deliver quality lessons for under-resourced African teachers in Mission schools, became greatly satisfied by the work of the girls in classes on dressmaking, knitting, sewing, home nursing, paediatric care, singing, basketry, laundry, sports and gardening amongst others (Chigwedere 2017:227). Her contributions are well described by Weiss (1999), Paul and Grundy (2011), and considered a female role model (Masengwe, Chimhanda \& Hove 2019). 'The girls rapidly gained in confidence and selfrespect and, becoming drill instructors, would give orders to the boys - an unheard of situation in Africa!' (Paul \& Grundy 2011:632). This challenged and continues to challenge contemporary constructions of gender in the COCZ, where women are allowed (Machingura \& Nyakuhwa 2015):

$[T]$ o sing, dance and lead praise and worship but only told to be quiet when it comes to preaching and occupying leadership positions like pastoral posts or eldership in the Church of Christ. (p. 92)

Todd proved that women can be exceptional in both academic and extra-curricular activities such as leadership, argumentation, speech and reading. This militated against gender stereotyping, oppression and domination using unjust prejudice advanced by the colonial system. This is a strong lesson for churches and communities that secure leadership positions for men who are in many times incapable of providing leadership in the church and community, which could benefit from gender diversity in their midst. Gender equality and equity has been difficult to achieve with more women advancing in formal jobs and men in informal jobs. That needs to be attended to.

\section{Diversification of the national economy through just land policy and practice}

The Shona of the LNR had suffered from internal attacks by the Ndebele raiders, and British colonial and divisive racial system for four decades. When Todd came, it marked a critical moment for the people who had lost land and animals through the 1930 Land Apportionment Act. Africans were overcrowded in reserves, but Todd bought large tracks of cheap land for use by blacks to grow crops and raise animals. Todd also donated 3000 acres of land to liberation war fighters who formed a cooperative with his daughter Judith, the Vukuzenzele Cooperative, to help war returnees with a place to settle as well as a means to survive (Nyoni 2018). Other white liberals who worked alongside Todd on this matter included Bishop Night-Bruce of the Methodist 
Church, John White nicknamed the Cyclone and Arthur Shearly Cripps, the Hurricane, whilst Garfield Todd was the white African Moses (Chigwedere 2017:231-232).

Shearly Cripps in a few years 'took it upon himself to raise money to buy land for the natives' (Makwasha 2011:240). Todd arrived in Zimbabwe during the land conflicts between black and white people. In 1951, Todd became enthusiastic about modernising the emerging economy of then Rhodesia and presided over the awkward Native Land Husbandry Act (NLHA 1951), wherein its first presentation to parliament in April 1951, Todd warned that Africans were justifiably afraid of the Bill that robbed them of their security of tenure. He advised that effort was needed to diversify and reorganise the reserves into the formal economy (Woodhouse 2018:86). When he became premier, he approached both the South African and United States governments to support a new system of land husbandry in native reserved areas financially. Hokonoui Farm became his practical exhibit for a diversified and formalised economy for African reserves. During the liberation struggle, African fighters hid on the farm as it was outside the colonial reprisals in search for liberationists. This has been fulfilled during the 2001-2003 fast track land reform programme (FTLRP) where the COCZ solicited to acquire Somabhula under Chief Lukuluba for in conference centre, boarding school and national centre (Masengwe \& Chimhanda 2019). African elites equated the NLHA (1951) with the Land Apportionment Act of 1930 because of the flawed modernist and technocratic approach meant to end ruralurban circular labour migration by maintaining grazing sustainability for rural cattle-holding elites and peasant farmers who relied on their draught power and manure. Todd attempted to reform the African Councils Act (1957) so as to reduce the powers concentrated in the hands of traditional chiefs and Native Commissioners derided by educated Africans (Mlambo 2009:53). Economic diversification would create a long-term inheritance for Africans if taught proper agricultural practices.

Furthermore, Todd gave up his missionary stipend from New Zealand when he won a parliamentary seat. This challenges wealth-amassing postmodernist leaders to be philanthropists and religionists rather than politicians only. Religion like state progress has been hindered by selfish attitudes on wealth rather than spreading income security to all who need it. It has always been found that when the material benefits of our neighbours are guaranteed, our material benefits are also secured. This is not economic redistribution, but the provision of opportunities for every person according to need. Shona Hunhuism (Baka 2018) thinks that:

$[M] y$ children have no right to feed on chicken meat when my neighbour's children are feeding on vegetable soup every day for if my chickens get lost, I have no right to ask my neighbour. (p. 1)

This is a local philosophy of equality, equity, togetherness, personhood, hospitality and accessibility to available opportunities for all people. Shona hunhu means that a 'person' is only defined by how they relate with others (Samkange \& Samkange 1980). Garfield Todd here is not only a lesson for the COCZ to be selfless and sacrificial but for the religious and nonreligious actors in the nation to consider using sane distribution and use of state land, especially following a warped land reform programme of 2001-2003.

\section{Advocacy for the Human Rights of Africans}

Todd's approach to human rights gives us big lessons on how advocacy must be done today. Writers (among whom Casey 2001) paint many faces of Garfield Todd, with his 1958 ouster as the stroke that broke the Camel's back:

Later, in 1962, Todd spoke before a United Nations Committee on Colonialism in one of his finest and most important speeches. Todd opposed a new constitution for Southern Rhodesia that would keep whites in control. (p. 492)

Even Joshua M.N. Nkomo described Todd saying (Weiss 1999):

$[O] n$ this particular occasion, his oratory was devastating. Facts against the 1961 Constitution flowed in fast sequence from his fingertips ... he spoke like one possessed and he got a most thunderous ovation from all the delegates except of course that of Britain. (p. 150)

Todd, who became involved in politics when he worked with Africans at Dadaya empathically considered his ascendancy to parliament as an opportunity to improve the life prospects for the people of the LNR, for he said that 'his 1957 franchise Bill cleared the way for multiracial trade unions' to undercut white nationalist interests on unions. This is important for human rights defence in the country.

\section{Todd's major contestations}

Todd's upright principles invited untold suffering upon him during the colonial era from Ian Douglas Smith for standing on the sides of Africans. His philosophy, 'Just keep throwing your bread upon the waters; if you're lucky, it will come back as ham sandwiches' (Lowry 2007a:176), helped him to forgive his persecutors continuously. Todd's sacrifice on initiating the colonial government to transform itself into a racial democracy provides huge lessons on how the Church and state should conduct themselves in public life. He was also admired by those he punished like Rev. N. Sithole after the 1947 Dadaya strike or trade unionist J.M.N. Nkomo after his ruthless and authoritarian invocation of the Public Order Act against the 1955 industrial unrest (Lowry 2007a:176). His ethos even under unjust political house arrest by the colonial government is an important lesson for contemporary politicians to acquire in their discharge of duty (Todd 1972).

\section{Todd's post-colonialism encounter with political leaders}

Post-colonial Zimbabwe became bedevilled by corruption and ethnic violence that led to the Gukurahundi atrocities. Garfield Todd became defiant against the then president of Zimbabwe, Robert Mugabe (Casey 2011). He took the opportunity to remind the government of independent 
Zimbabwe to invest in people, public institutions and national wealth. Todd carved his name on human hearts and hence has appeared in many writings, films and short stories as a beacon of colonial and post-independent Zimbabwe. As a human letter written on human hearts (2 Cor 3:1-3), his family life and citizenship were threatened under the Mugabe regime the same way he went under indefinite house arrest during the Smith regime (Casey 2005:743-744, 2007; Landan \& Driver 1990; Lowry 2007b; Makuwe 2019; Mount 1966; Mungazi 1999; Paul \& Grundy 2011; Sell 2010; Weiss 1999; West 1992). Robert Mugabe, however, recognised his lasting legacy by posthumously making him a national hero, yet he died an illegal resident after his citizenship status was stripped away for confronting Mugabe on the 1982-1987 Gukurahundi atrocities (Mungazi 1999:130; Pritchard 2018:95) and other political ills.

\section{Lessons for Christians in Zimbabwe and beyond}

Although some criticise the knighted (1986) statesman for taking his freedom too far, ' $[h]$ is followers never understood where he was going or why he was going there ... or where he had come from' (Ranger 2008:226). Uniquely (Casey 2004):

[S]ir Garfield Todd (1908-2002) was the first missionary from any Christian tradition to rise to a head of state when he became the Prime Minister of Southern Rhodesia [Zimbabwe] (1953-1958). (p. 491)

His theology and actions inculcated passions in his students and local colleagues. He lived his faith and is never quoted on doctrinal controversies in the COCZ, and his ecumenical values were lived by transforming the Southern Rhodesia Council of Churches (now the Zimbabwe Council of Churches) into a vibrant and formidable ecumenical voice against racism and colonialism in Zimbabwe. Todd brought churches together under the auspices of the Rhodesian Christian Council (RCC, now the Zimbabwe Council of Churches [ZCC]), to fight on the side of the nationalists, who also joined hands with the Rhodesian Catholic Bishops' Conference (RCBC) and its instrumental non-goverment organisations (NGOs) like Catholic Relief Service (CRS) wherein ZCC formed Christian Care (CC) in 1967 to assist in humanitarian needs such as feeding and clothing the liberation fighters, evictees and uprooted communities. This influenced social and political change in the country as the church went on to the front to fight against racism and to defend African people's humanity. Contemporary church leaders need to examine how they carve their names in human hearts, so they can become human letters in human hearts.

This challenges the COCZ and other denominations to consider their own place in the public arena as enshrined in the Declaration and Address by the RM fathers that ' $[w] \mathrm{e}$ are Christians only, but not the only Christians'. The Church is the only institution with the acumen and moral intelligence to unite all people to defend the rights of the downtrodden masses to achieve their aspirations on health, food security, education, politics and gender diversity. All churches in the country can initiate Christian cooperation and denominational unity useful for uniting political parties. Todd lived and worked for problematic contexts, but guided by Christian principles in which he was reared, he made an impact in colonial and postcolonial Zimbabwe. With this, the Church can address issues of corruption, election violence, hate speech, moral decadency and lack of love for people and humanity in Zimbabwe. This may create a better Zimbabwe for generations after our own.

\section{Lessons for political leadership in Zimbabwe}

The pedagogical lessons of Garfield Todd on human security, gender equality, church governance and human well-being that require review within the contemporary Christian fraternity do not only challenge the COCZ but political parties also to take up a leading role on justice, equality, truth, equity and unity amongst others. His radical paternalism supported African transformation. He used his rise into parliament and premiership to advance the African cause. Political leaders have power and can use it to reform the nation into a democratic and peaceful nation that accepts all tribes and races in the country. Contemporary politicians can take their ethos from his Christian heritage (Todd 1972) to change nations in the shortest time possible like he prepared Africans for the liberation struggle that lasted for 5 years. Politicians have lessons to learn on how to transform postmodernist states. Todd's reformist approach could reconcile racial politics and nationalist liberalism to attain multi-racial democracy in post-colonial Zimbabwe (King 2001:12). Politicians need to learn to live and work for the generations after their own by carving their names on human hearts rather than tombstones - letters written on human hearts.

\section{Lessons for future generations in Zimbabwe and beyond}

Todd's sacrifice on initiating the colonial government to transform itself into a racial democracy provides huge lessons on how future generations should conduct themselves in public life. Whilst they may have power, they may need to use it to advance the downtrodden and to transform their communities and states to become much more habitable. Ethics and leadership are important hallmarks of political reform in a nation that advances citizens' interests. Democracy should accept diversity and talent rather than sameness for sameness' sake. This will assist future generations to be multicultural and pluralist in their discharge of duties. This can make future societies caring and responsible for all of humanity and creation rather than selfish and wanton benefits for individuals. Future generations need to be people of their time, guided by their ethical principles, live and work for their contexts. 


\section{Conclusion}

Sir Reginald Stephen Garfield Todd (1908-2002), an exmissionary of the Disciples of Christ sturdily New Zealander by 'birth', who came and Zimbabwean by 'adoption' was committed to serve the lives of Africans by meeting their medical crises, food security needs, education, self-determination and aesthetic needs as enshrined in the Gospel of Jesus Christ (Todd 1972). He was a radical paternalist in favour of Africans, and took an opportunity to use his rise into the parliament and premiership to advance the African cause. His reformist policies and rhetorics intended to peacefully transform Zimbabwe from a racist colony into a multi-racial democracy. His ethos is an important lesson for contemporary politicians and Christians in their discharge of duty (Todd 1972) for 5 years, and he prepared Zimbabwean middle-classes who could sustain a war of liberation and lead the country into independence. This is a legacy we cannot afford to ignore for the transformation of postmodernist states. The Church, political parties and Zimbabweans can learn to carve their names on human hearts rather than tombstones and become letters written on human hearts as they advance the cause and interests of generations after them.

\section{Acknowledgements}

This article was initiated by a 5-min message from Pastor Godfrey Ndiriwenyu of Emganwini Church of Christ, at a Men's Fellowship in Bulawayo, Mabutweni on 28 August 2016, who preached on leaving a legacy in our places of ministry. He used 2 Corinthians, and left the men in quandary as he demanded them to consider themselves as 'human letters written on people's hearts'. He stated:

A more holistic definition of legacy is when you are genuinely grounded in offering yourself and making a meaningful, lasting and energising contribution to humanity by serving a cause greater than your own.

He further stated: 'Legacy is what you do between now and eternity'. This message was fit for Garfield Todd, so we reason. Shamuyarira in his book, Crisis in Rhodesia, inscribed: 'I had a firm belief that all [what] Europeans needed [to change their attitudes to Africans] were persons to interpret genuine African thought for them' (Todd 1966:17).

\section{Competing interests}

The authors declare that they have no financial or personal relationships that may have inappropriately influenced them in writing this article.

\section{Authors' contributions}

G.M. conceptualised and wrote the first draft. B.D. analysed the first draft, completed the write-up and edited the manuscript.

\section{Ethical considerations}

This article followed all ethical standards for research without direct contact with human or animal subjects.

\section{Funding information}

This research received no specific grant from any funding agency in the public, commercial or not-for-profit sectors.

\section{Data availability}

Data sharing is not applicable to this article as no new data were created or analysed in this study.

\section{Disclaimer}

The views and opinions expressed in this article are those of the authors and do not necessarily reflect the official policy or position of any affiliated agency of the authors.

\section{References}

Banana, C.S., 1989, Turmoil and tenacity, Zimbabwe 1980-1990, The College Press, Harare.

Bhebhe, M., 2013, An African culture of multiple religiosity: The perspective of the Church of Christ in Zimbabwe, Lambert Academic, Saarbrucken.

Berryhill, C.M., 1988, 'Alexander Campbell's natural rhetoric of evangelism', Restoration Quarterly 30(2/3), 111-124.

Casey, M.W., 2001, 'From British Ciceronianism to American Baconianism: Alexander Campbell as a case study of a shift in rhetorical theory', Southern Communication Journal 66(2), 151-166. https://doi.org/10.1080/10417940109373194

Casey, M.W., 2004, “'Come let us reason together": The heritage of the Churches of Christ as a source for rhetorical invention', Rhetoric and Public Affairs 7(4), 487-498. https://doi.org/10.1353/rap.2005.0024

Casey, M.W., 2005, 'Todd, Sir Garfield (1908-2002) and Lady Grace (1911-2000)', in P. Bowers et al. (eds.), The encyclopaedia of the tone-Campbell movement: Christian churches, Churches of Christ and the Christian Church, pp. 743-744, Grand Rapids, MI.

Casey, M.W., 2007, The Rhetoric of Sir Garfield Todd: Christian imagination and the dream of an African democracy, Balor University Press, Waco, TX.

Casey, M.W. \& Foster, D.A. (eds.), 2002, The Stone-Campbell Movement: An international religious tradition, University of Tennessee Press, Knoxville, TN.

Chigwedere, A.S., 2017, The White Heroes of Zimbabwe: John White, Arthur Shearly Cripps, Reginald Garfield Todd, Jean Grace Todd, Mutapa Publishing House, Harare.

De Gruchy, J., 1995, Christianity and Democracy: A theology for just world order, Cambridge University Press, Cambridge.

Fraenkel, J., 2015, 'Equality of rights for every civilized man south of the Zambezi': Electoral engineering in Southern Rhodesia, 1957-65', Journal of Southern African Studies 41(6), 1167-1180. https://doi.org/10.1080/03057070.2015.1116231

Harrell, D.E. (Jr.), 1966, Quest for a Christian America: The Disciples of Christ and American society to 1866, Disciples of Christ Historical Society, Nashville, TN.

Hintz, S., 1972, 'The political transformation of Rhodesia, 1958-1965', African Studies Review 15(2), 173-183. https://doi.org/10.2307/523917

Holderness, H., 1985, Lost Chance: Southern Rhodesia 1945-58, Zimbabwe Publishing House, Harare.

Hughes, R.T., 1996, Reviving the ancient faith: The story of the Churches of Christ in America, Eerdmans Publishing Company Private Limited, Grand Rapids, MI.

Kapungu, L., 1974, Rhodesia: The struggle for freedom, Orbis Book, New York, NY.

Kealy, P., 1963, The politics of partnership: The Federation of Rhodesia and Nyasaland, Penguin African Library, London.

King, A., 2001, 'Identity and decolonisation: The policy of partnership in Southern Rhodesia 1945-62', PhD thesis, University of Oxford.

Landan, A. \& Driver, R. (Producers), 1990, Hokonui Todd, 47 min. Film. Richard Driver (Director), Linehurst Films.

Leaver, J.D., 2006, 'Multiracialism and nationalisms: A political retrospective on 1950 s Southern Rhodesia (Colonial Zimbabwe)', Journal of Third World Studies 23(2), 175.

Leys, C., 1959, European politics in Southern Rhodesia, Clarendon Press, Oxford.

Lowry, D., 2007a, 'The impact of anti-communism on White Rhodesian political culture, ca.1920s-1980s', Cold War History 7(2), 169-194. https://doi. org/10.1080/14682740701284108

Lowry, D., 2007b, Todd, Sir (Reginald Stephen) Garfield (1908-2002). Oxford Dictionary of National Biography, OUP, Oxford. 
Lusby, J.L., 1990, Historical survey of Central African Mission, Zimbabwe, Kentucky Christian College Press, Kentucky, TX.

Machingura, F. \& Nyakuhwa, P., 2015, 'Sexism: A hermetical interrogation of Galatians 3: 28 and women in the Church of Christ in Zimbabwe [COCZ]', The Journal of Pan African Studies 8(2), 92-113.

Makwasha, G.M., 2011, 'The quest for God's irregulars: The legacy of Arthur Shearly Cripps and the role of the Anglican Church in nation building in Zimbabwe today' Missionalia 39(3), 228-247.

Makuwe, S., 2019, Black lover, Auckland Theatre Company, Auckland.

Masengwe, G. \& Chimhanda, F.H., 2019, 'Towards authentic transformation in the Church of Christ in Zimbabwe', HTS Theological Studies 75(1), 1-11. https://doi. org/10.4102/hts.v75i1.4776

Masengwe, G., 2020, 'The church of Christ in Zimbabwe: Identity- and Missioncontinuity [in Diversity]', Unpublished PhD thesis, Systematic Theology, UNISA.

Masengwe, G., Machingura, F. \& Magwidi, E., 2012, 'An excavation on Church Governance: The Question of Autonomy in the light of the disempowered African Church Converts in the Church of Christ in Zimbabwe (COCZ)', Journal of Research in Peace, Gender and Development 2(9), 185-194.

Mason, P., 1960, Year of Decision: Rhodesia and Nyasaland in 1960, Oxford University Press, Oxford.

Mlambo, A.S., 2009, 'From the Second World War to UDI, 1940-1965', in B. Raftopoulos \& A. Mlambo (eds.), Becoming Zimbabwe: A history from the pre colonial period to 2008, pp. 75-114, Weaver Press, Harare.

Mount, G.S., 1966, Todd, Reginald Stephen Garfield. Historical Dictionary of the British Empire, vol. 2, Westport Press, Westport.

Mungazi, D.D., 1999, The last British liberals in Africa: Michael Blundell and Garfield Todd, Praeger, Westport, CT.

Nyoni, P.B., 2018, Interview, Pumula Church of Christ, 17 August 2018, Personal offices, Bulawayo.

Paul, S. \& Grundy, T., 2011, 'The Dadaya years: The challenge of understanding Garfield Todd', The Round Table 100(417), 629-638. https://doi.org/10.1080/003 58533.2011.633378

Pritchard, J., 2018, 'Race, identity, and belonging in early Zimbabwean nationalism(s), 1957-1965', PhD thesis, University of Cambridge.

Raftopoulos, B., 1995, 'Nationalism and labour in Salisbury 1953-1965', Journal of Southern African Studies 21(1), 79-93.

Ranger, T.O., 2008, 'A Todd succession? A political family and modern Zimbabwe', (Review Article), Journal of Southern African Studies 34(1), 225-227.

Richards, K. \& Govere, E., 2003, 'Educational legislation in colonial Zimbabwe (1899-1979)', Journal of Educational Administration and History 35(2), 137-151. https://doi.org/10.1080/0022062032000119822
Samkange, S. \& Samkange, T.M., 1980, Hunhuism or Ubuntuism: A Zimbabwean indigenous political philosophy, Graham, Harare.

Sell, B., 2010, 'Garfield Todd: Leader with a conscience', in B. Sell (ed.), Kiwi Heroes: 50 Courageous New Zealanders, pp. 268-273, Allen \& Unwin, Crows Nest.

Todd, G.S., 1985, 'Foreword', in H. Holderness (ed.), Lost chance: Southern Rhodesia 1945-58, pp. 1-3, Zimbabwe Publishing House, Harare.

Todd, J., 1966, Rhodesia, Sagwick \& Jackson Publishers, London.

Todd, J., 1972, The right to say no, Sagwick \& Jackson Publishers, London.

Todd, J., 1982, An act of treason: Rhodesia 1965, Longman, Harare.

Todd, S.R.G., 1941, Report to New Zealand Churches of Christ of seven years at Dadaya. Todd Paper Paul Collection (TPPC), Bodleian Library of Commonwealth and African Studies, Rhodes House, Oxford.

Tucker, W.E. \& McAllister, L.G., 1975, Journey in faith, Christian Board of Publication, St. Louis, MO.

Vundla, C., 2015, The White Lion of Zimbabwe Sir Garfield Todd, 17 September, viewed 12 June 2020 , from http://bulawayo24.com/columnist/Cde+Cakes+Vundla+Zapu +Youth+Front+Leader.

Webb, H.E., 2003, In search of Christian unity: A history of the Restoration Movement, rev edn., Abilene Christian University Press, Abilene, TX.

Weiss, R. \& Parpart, J., 1999, Sir Garfield Todd and the making of Zimbabwe, British Academic Press, London.

Welensky, S.R., 1964, Welensky's 4000 Days: The life and death of the Federation of Rhodesia and Nyasaland, Collins, London.

West, M.O., 1992, 'Ndabaningi Sithole, Garfield Todd and the Dadaya School strike of 1947', Journal of Southern African Studies 18(2), 297-316. https://doi. org/10.1080/03057079208708316

White, L., 2015, Unpopular Sovereignty: Rhodesian Independence and African Decolonization, University of Chicago Press, Chicago.

Williams, D.N., Allen, D. \& Blowers, P.M. (eds.), 2013, The Stone-Campbell Movement: A global history, The Chalice Press, Nashville, TN.

Wilson, K.B., 1990, 'Ecological dynamics and human welfare: A case study of population, health and nutrition in Southern Zimbabwe', PhD thesis, University of London.

Woodhouse, S., 2018, Garfield Todd: The end of the liberal dream in Rhodesia, Weaver Press, Harare.

Zvobgo, C.J., 1996, A history of Christian missions in Zimbabwe, 1890-1939, Mambo Press, Gweru.

Zvobgo, C.J.M., 2009, A history of Zimbabwe, 1890-2000 and Postscript, Zimbabwe, 2001-2008, Cambridge Scholars, Gweru. 